\title{
An Unbalanced Act: A Criticism of How the Court of Arbitration for Sport Issues Unjustly Harsh Sanctions by Attempting to Regulate Doping in Sport
}

Melissa Hewitt

Indiana University Maurer School of Law, melissamhewitt92@gmail.com

Follow this and additional works at: https://www.repository.law.indiana.edu/ijgls

Part of the Entertainment, Arts, and Sports Law Commons, International Law Commons, and the Transnational Law Commons

\section{Recommended Citation}

Hewitt, Melissa (2015) "An Unbalanced Act: A Criticism of How the Court of Arbitration for Sport Issues Unjustly Harsh Sanctions by Attempting to Regulate Doping in Sport," Indiana Journal of Global Legal Studies: Vol. 22 : Iss. 2 , Article 16.

Available at: https://www.repository.law.indiana.edu/ijgls/vol22/iss2/16

This Note is brought to you for free and open access by the Law School Journals at Digital Repository @ Maurer Law. It has been accepted for inclusion in Indiana Journal of Global Legal Studies by an authorized editor of Digital Repository@Maurer Law. For more information, please contactrvaughan@indiana.edu.

\section{$\Psi$}

JEROME HALL LAW LIBRARY

INDIANA UNIVERSITY

Maurer School of Law
Blooming ton 


\title{
An Unbalanced Act: A Criticism of How the Court of Arbitration for Sport Issues Unjustly Harsh Sanctions by Attempting to Regulate Doping in Sport
}

\author{
MELISSA HEWITT ${ }^{\star}$
}

\begin{abstract}
To participate in international competitions, countries must submit to the doping rules set forth in the World Anti-Doping Code (the Code), a document brought into being by the World Anti-Doping Agency (WADA). Under the Agency's Code, athletes are required to commit to mandatory binding arbitration in the Court of Arbitration for Sport (CAS), which gives them few chances for review of unjustly harsh sanctions. The CAS needs to re-examine its method of appealing doping cases because WADA's current strict liability scheme, coupled with the CAS's transnational jurisdiction, continually violates the rights of international athletes.
\end{abstract}

\section{INTRODUCTION}

After training as a gymnast since she was four-years-old, sixteenyear-old Romanian athlete Andreea Răducan finally found herself on the world's stage when she was chosen to represent her country at the 2000 Olympic Games in Sydney, Australia. ${ }^{1}$ Before competing in the Women's Individual All-Around Event, Răducan complained to her team doctor of having cold symptoms, for which the doctor administered a standard cold and flu medication. ${ }^{2}$ Răducan went on to win the Women's Individual All-Around competition. After the event, she submitted to a

* Managing Editor, Indiana Journal of Global Legal Studies, Volume 22; JD 2015, Indiana University Maurer School of Law; BA 2012, Cornell University. The author would like to thank the editors and reviewers for their helpful and constructive comments and suggestions that contributed to improving the final version of this article.

1. Raducan v. IOC, CAS ad hoc Division OG 00/011, at 1, Award of 28 Sept. 2000 (Ct. Arb. for Sport 2000), http://www.5rb.com/case/raducan-v-ioc/.

2. See id. at 2 .

Indiana Journal of Global Legal Studies Vol. 22 \#2 (Summer 2015)

(c) Indiana University Maurer School of Law 
drug test that revealed trace amounts of pseudoephedrine, a banned substance found in the cold medicine she had taken earlier. ${ }^{3}$ Based on the results of the drug test, Olympic officials disqualified Răducan from the event and stripped the young gymnast of her gold medal. ${ }^{4}$ After reviewing the case, a panel from the Court of Arbitration for Sport (CAS) acknowledged that the small amount of pseudoephedrine could not have enhanced Răducan's performance, but it nonetheless penalized her for her accidental ingestion of the substance. ${ }^{5}$

Since Răducan, there have been scores of other athletes who have either been stripped of their medals or suspended for the accidental ingestion of banned substances. Take U.S. Swimming superstar Jessica Hardy, for example. In 2008, Hardy, a world record holder in the Women's 100-meter Breaststroke, tested positive for clenbuterol, a banned anabolic agent. ${ }^{6}$ Though she had taken numerous steps to confirm that the supplement was safe for consumption, she was severely punished for her accidental ingestion of a banned substance. ${ }^{7}$ Before consuming the product, Hardy meticulously researched the supplement: she had personal conversations with the manufacturers of the supplement who assured her that it was pure; she obtained the supplement directly from the manufacturer instead of through a third party; and she consulted with her swimming coaching staff, including the team's nutritionist, who again assured her that the product was fit for consumption. ${ }^{8}$ Despite her efforts to remain drug-free, Hardy tested positive for clenbuterol four weeks before the 2008 Olympic Games in Beijing. ${ }^{9}$ Though she had been taking the supplements for eight months

3. See id.

4. See Richard Sandomir, Sydney 2000: Gymnastics; Despite Losing Appeal, Romanian Says Her Heart Is at Peace, N.Y. TIMES, Sept. 29, 2000, at 1, available at http://www.nytimes.com/2000/09/29/sports/sydney-2000-gymnastics-despite-losing-appealromanian-says-her-heart-is-at-peace.html.

5. See Ryan Connolly, Balancing the Justices in Anti-Doping Law: The Need to Ensure Fair Athletic Competition Through Effective Anti-Doping Programs vs. the Protection of Rights of Accused Athletes, 5 VA. SPORTS \& ENT. L.J. 161, 181 (2006).

6. See Nathaniel Vinton, Swimmer Jessica Hardy Claims Doping Innocence - But Tests Say Otherwise, N.Y. DAILY NEwS (July 26, 2008, 11:22 PM), available at http://www.nydailynews.com/sports/more-sports/swimmer-jessica-hardy-claims-dopinginnocence-tests-article-1.353320; Anabolic agents stimulate muscle growth and can contribute to an increase in lean mass and general gain usually achieved through highintensity exercise. This creates the potential for an athlete to gain unfair advantage. See Fred Hartgens \& Harm Kuipers, Effects of Androgenic-Anabolic Steroids in Athletes, 34 SPORTS MED. 513, 535-43 (2004) (discussing the effects of anabolic agents on athletes).

7. See World Anti-Doping Agency v. Hardy, CAS 2009/A/1870, at 3, Award of 21 May 2010 (Ct. Arb. for Sport 2010), https://www.wada-ama.org/en/resources/legal/cas-wada-vhardy-usada.

8. Id. $\uparrow 72$

9. Id. ข 6 . 
without failing a drug test, lab technicians alleged that her nutritional supplements contained the banned substance. Hardy was forced to withdraw from the 2008 Olympic Games, and instead of defending her title as world-record holder, she found herself defending not only her reputation against allegations of cheating, but also her career against a two-year suspension from swimming competitions. ${ }^{10}$ These and other harsh rulings were handed down at the direction of the World AntiDoping Agency (WADA), the drug-free sport enforcer of the international sporting world.

Part I of this paper will provide information on the origin of the World Anti-Doping Agency and the World Anti-Doping Code, and examine how the Code functions in the international sports realm. Part II will explain the origin and structure of the Court of Arbitration for Sport and briefly discuss the scope of its power and how this power affects athletes who compete at the international level. Part III will explore the benefits and costs of delegating international sports disputes to the CAS. Part III will also describe the relationship formed between nation-states and a transnational body and what this relationship teaches us about globalization. Part IV suggests a reform to WADA's strict liability model that will decrease the number of violations against innocent athletes. In Part V, this paper concludes that for the CAS's transnational jurisprudence to be more effective, there needs to be a mechanism put in place that will protect athletes against being unjustly sanctioned.

\section{THE WORLD ANTI-DOPING AGENCY}

The World Anti-Doping Agency was formed in response to a dramatic increase in the number of doping scandals that shook the international sports world at the Tour de France in the summer of 1998. ${ }^{11}$ To help combat the increasing popularity of doping in competitions, the International Olympic Committee (IOC) hosted the World Conference on Doping in Sport in Lausanne, Switzerland, which

10. See id. 19 7-15. The CAS eventually reduced Hardy's suspension to one year, even though WADA appealed this decision and sought a two-year suspension for the swimmer.

11. A Brief History of Anti-Doping, WORLD ANTI-DOPING AGENCY (2015), https://www.wada-ama,org/en/who-we-are/a-brief-history-of-anti-doping (last visited Mar. $28,2015)$. Officials found large quantities of performance enhancing drugs in a car belonging to one of the French cycling teams. A follow up investigation led to the opening of a separate case into the Dutch cycling team, and the subsequent searching of many teams during the race. The investigation revealed systematic doping, and suspicion was raised that there may have been a widespread network of doping involving many teams of the Tour de France. 
produced the Lausanne Declaration on Doping in Sport. ${ }^{12}$ The Declaration "provided for the creation of an independent international anti-doping agency," and WADA was subsequently established upon this premise with the goal to "promote and coordinate the fight against doping in sport internationally." 13 A second World Conference on Doping in Sport was held in March 2003 where approximately 1,200 delegates representing eighty governments, the IOC, all International Federations for Olympic Sports, athletes, and others came together to review and adopt the World Anti-Doping Code as the basis for the fight against doping in sport. ${ }^{14}$ The document was meant to promote a harmonized set of anti-doping rules in the international sporting world. ${ }^{15}$ According to WADA, "the Code is the core document that provides the framework for harmonized anti-doping policies, rules and regulations within sport organizations and among public authorities." 16 Before the Code, many organizations had differences in their lists of banned substances, rules, procedures, and penalties; the implementation of the Code provided a more uniform way of regulating doping prevention. ${ }^{17}$

Because the Code was created to ensure effective anti-doping programs, the drafters adopted a strict liability framework that guaranteed suspensions, even for innocent athletes like Răducan and Hardy who never sought to gain a competitive edge. ${ }^{18}$ To date, there have been three versions of the Code, each one outlining an argument in favor of strict liability. ${ }^{19}$ Most notably, the 2003 Code stated, "[i]t is true

12. Id.

13. Who We Are, WoRLD ANTI-DOPING AGENCY (2015), https://www.wada-ama.org/en/ who-we-are (last visited Mar. 28, 2015).

14. Meredith Lambert, The Competing Justices of Clean Sport: Strengthening the Integrity of International Athletics While Affording A Fair Process for the Individual Athlete Under the World Anti-Doping Program, 23 TEMP. INT'L \& COMP. L.J. 409, 415 (2009).

15. See id. at 414 .

16. Id. at 414 n.56.

17. See generally Jessica K. Foschi, A Constant Battle: The Evolving Challenges in the International Fight Against Doping in Sport, 16 DUKE J. CoMP. \& INT'L L. 457, 459-61 (2006) (explaining the anti-doping systems that existed prior to the WADA regime).

18. See Karen Crouse, For Swimmer, Ban Ends, but Burden Could Last, N.Y. TIMES, Aug. 8, 2010, SP1, available at http:/www.nytimes.com/2010/08/08/sports/08hardy.html (describing Hardy's positive test for Clenbuterol and her struggle to return to competition).

19. World Anti-Doping Agency, World Anti-Doping Code 2003, at art. 2.1 (2003), available at https://wada-main-prod.s3.amazonaws.com/resources/files/wada_code_2003_en.pdf [hereinafter WADA Code 2003]; World Anti-Doping Agency, World Anti-Doping Code 2009, at art. 2.1 (2009), available at https:/wada-main-prod.s3.amazonaws.com/resources/files/ wada_anti-doping_code_2009_en_0.pdf [hereinafter WADA Code 2009]; World Anti-Doping Agency, World Anti-Doping Code 2015, at art. 2.1 (2015), available at https://wada-main- 
that a strict liability test is likely in some sense to be unfair in an individual case, such as ... where the [a]thlete may have taken medication as the result of mislabeling or faulty advice for which he or she is not responsible ...."20 Though the drafters acknowledged that the current framework facilitates unfairness, they justify their position by inferring that some amount of unfairness is inevitable. ${ }^{21}$

There are, of course, many good arguments in favor of this strict liability framework. For example, in the 2015 Code, the drafters wrote that sanctions would be even more inequitable than they currently are if "[a]thletes from the same country who test positive for the same Prohibited Substance under similar circumstances should receive different sanctions only because they participate in different sports." 22 And regarding the inadvertent ingestion of banned substances, one CAS panel has said that

[t]oo literal an application of the principle 'Nulla poena sine culpa' could have damaging consequences on the effectiveness of anti-doping measures. Indeed, if, for each case, the sports federations had to prove the intentional nature of the act (desire to dope to improve one's performance) in order to be able to give it the force of an offence, the fight against doping would become practically impossible. ${ }^{23}$

While WADA's justification in the first instance is understandable, it fails to take into account that all sports are not created equal. A suspension in one sport might be career ending, while a suspension in another sport might be seen as a mere slap on the wrist. ${ }^{24}$ Regarding the second justification offered by the CAS panel and the inadvertent

prod.s3.amazonaws.com/resources/files/wada-redline-2015-wadc-to-2009-wadc-en.pdf [hereinafter WADA Code 2015] (last visited Mar. 28, 2015).

20. WADA Code 2003, supra note 19, at comment to art. 2.1.1 (this language has been removed from the most recently published 2015 Code, but WADA still maintains that athletes will continue to be charged with an anti-doping violation without regard to their fault).

21. See id.

22. WADA Code 2015, supra note 19, at comment to art. 10.

23. C. v. Federation Internationale de Natation Amateur (FINA), TAS 95/141, Sentence du 22 avril 1996, 1, 5 (Ct. Arb. for Sport 1996), available at http://jurisprudence. tas-cas.org/sites/CaseLaw/Shared\%20Documents/141.pdf.

24. For example, compare gymnastics, which is age sensitive, to equestrian, which had the oldest competitor in the London 2012 Olympics at 71 years old. London 2012's Oldest Competitor, Hiroshi Hoketsu, Takes The Reins, THE GUARDIAN, Aug. 2, 2012, available at http:/www.theguardian.com/sport/2012/aug/02/london-2012-oldest-hiroshi-hoketsu. 
ingestion of a banned substance, some argue that justice would be better served if an athlete could be exonerated by proving: "1) that he or she did not intend to ingest the banned substance, and 2) that the ingestion of the substance had no performance-enhancing effect." 25

Whatever opinions people have about the fairness of the Code, the fact still remains that in order to compete in the Olympics, countries must submit to the rules of the Code and therefore subject their athletes to the rules of the Code. ${ }^{26}$ The Code instructs that in the event of a dispute regarding the harshness of a sanction under WADA's strict liability scheme, all cases must be brought before the CAS, which has exclusive jurisdiction over doping appeals involving international-level athletes or international events. ${ }^{27}$ In addition to the Olympics, other major international sports organizations, like the Fédération Internationale de Football Association (FIFA), have made the CAS the exclusive arbitral body for disputes arising during the course of competition. ${ }^{28}$ The Code is also enforced by the vast majority of sporting federations and countries around the globe. ${ }^{29}$

\section{THE CREATION OF THE COURT OF ARBITRATION FOR SPORT AND ITS ROLE IN THE RESOLUTION OF INTERNATIONAL SPORTS DOPING DISPUTES}

\section{A. Origins}

The increasing number of international sports disputes beginning in the early 1980s highlighted the need for an independent authority specializing in producing "quick, inexpensive, and binding" decisions on sports-related matters. ${ }^{30}$ More specifically, the international sports

25. Connolly, supra note 5, 182 n.80. Connolly acknowledges, however, that this raises "issues of judicial efficiency and the scientific difficulty of establishing efficacy" because "[a]ctual performance enhancement is nearly impossible to conclusively prove or disprove."

26. See The Code, WoRLD ANTI-DOPING AGENCY, https://www.wada-ama.org/en/whatwe-do/the-code (last visited Mar. 28, 2015).

27. WADA Code 2003, supra note 19, at art. 13.3 .

28. In addition to doping disputes, the CAS handles cases regarding employment contracts, field of play decisions, and another kind of dispute arising out of an international sports competition. See Types of Disputes Submitted to the CAS, WORLD ANTI-DOPING AGENCY, http://www.tas-cas.org/en/general-information/history-of-the-cas.html (last visited Mar. 28, 2015).

29. Code Signatories, WORLD ANTI-DOPING AGENCY, https://www.wada-ama.org/en/ what-we-do/the-code/code-signatories\#GovernmentFundedOrganizations (last visited Mar. 28, 2015); National Anti-Doping Organizations (NADO), WORLD ANTI-DOPING AGENCY, https://www.wada-ama.org/en/who-we-are/anti-doping-community/national-anti-dopingorganizations-nado (last visited Mar. 28, 2015).

30. IAN S. BLACKSHAW, SPORT, MEDIATION AND ARBITRATION 151 (Robert C.R. Siekmann \& Janwillem Soek eds., 2009). 
realm needed a body to "deal with crises of legitimacy in the sports world' and to become the supreme forum for international sport." 31

In response to the growing number of disputes, then-IOC President H.E. Juan Antonio Samaranch had the idea of creating a sports-specific jurisdiction whose sole responsibility would be to resolve disputes related to sports and to pronounce binding decisions on these matters. ${ }^{32}$ In 1982, IOC member H.E. Judge Keba Mbaye, who was then a judge at the International Court of Justice (ICJ), led a group of IOC members who were "tasked with drafting a document that would quickly become the 'Court of Arbitration for Sport,' and the idea of creating an arbitral jurisdiction dedicated to resolving disputes related to sport had thus firmly been launched." 33

\section{B. Structure and Governance}

The International Council of Arbitration for Sport (ICAS) acts as the supreme organ of the CAS, and it exists mainly to "safeguard the independence of the CAS and the rights of the parties appearing before it." 34 The ICAS is made up of twenty members, all of whom must "be high-level jurists well-acquainted with the issues of arbitration and sports law."35 All the members are required to sign a declaration in which they undertake "to exercise their function personally, with total objectivity and independence." ${ }^{36}$ Section $\mathbf{S 6}$ of the CAS Code gives ICAS the power to appoint CAS arbitrators, amend the CAS Code, and elect the presidents of the Ordinary and Appeals Divisions of the CAS. ${ }^{37}$ In essence, the ICAS has overwhelming influence over the management, administration, and regulation of the CAS. ${ }^{38}$

31. Rachelle Downie, Improving the Performance of Sport's Ultimate Umpire: Reforming the Governance of the Court of Arbitration for Sport, 12 MELB. J. INT'L L. 315, 334 (2011) (quoting Richard H McLaren, Twenty-Five Years of the Court of Arbitration for Sport: A Look in the Rear-View Mirror, 20 MARQ. SporTS L. REV. 305, 306 (2010)); Michael Straubel, Enhancing the Performance of the Doping Court: How the Court of Arbitration for Sport Can Do Its Job Better, 36 LOY. U. CHI. L.J. 1203, 1206 (2005).

32. See Downie, supra note 31 , at 321 .

33. Matthieu Reeb, The Court of Arbitration for Sports (CAS), in DIGEST OF CAS AWARDS 1986-1998, at XXIII (Matthieu Reeb ed., 1998).

34. BLACKSHAW, supra note 30 , at 153.

35. REEB, supra note 33, at XXVIII.

36. Ct. Arb. for Sport, Code of Sports-Related Arbitration 2013 Edition, S5 (Jan. 3, 2013), http//www.tas-cas.org/fileadmin/user_upload/Code20201320corrections20 finales20_en_pdf.

37. See id, at $\mathrm{S} 6$ for a complete list of functions of the ICAS.

38. Downie, supra note 31 , at 318-19. 
The CAS maintains a minimum of 150 members through which the body carries out its arbitral duties. ${ }^{39}$ In building the list of arbitrators, the ICAS must choose the candidates as follows:

- four members are appointed by the International Sports Federations (IFs), viz. three by the Association of Summer Olympic IFs (ASOIF) and one by the Association of Winter Olympic IFs (AIOWF), chosen from within or outside their membership;

- four members are appointed by the Association of the National Olympic Committees (ANOC), chosen from within or outside its membership;

- four members are appointed by the International Olympic Committee (IOC), chosen from within or outside its membership;

- four members are appointed by the twelve members of ICAS listed above, after appropriate consultation with a view to safeguarding the interests of the athletes; and

- four members are appointed by the sixteen members of ICAS listed above, chosen from among personalities independent of the bodies designating the other members of the ICAS. ${ }^{40}$

There are currently 330 CAS arbitrators, who represent the major geographical regions: Africa, North America, Central America and the Caribbean, South America, Asia, Europe, and Oceania. ${ }^{41}$

\section{The Scope of the CAS's Power}

Headquartered in Lausanne, Switzerland, and based on Swiss law, the CAS is a self-regulating body governed by its own rules. ${ }^{42}$ Because

39. Code of Sports-Related Arbitration 2013 Edition, supra note 36, at S13.

40. Id. at S4.

41. Ct. Arb. for Sport, List of Arbitrators (General List), http://www.tascas.org/en/arbitration/list-of-arbitrators-general-list.html (last visited Mar. 29, 2015).

42. See JAMES A. R. NAFZIGER, INTERNATIONAL SPORTS LAW 40-41(2d ed. 2004). 
an overwhelming majority of sports bodies have delegated disputes to the CAS, the power of this body continues to grow, and it has become a major private legal entity with an "ever-increasing role in the development of this sports-specific jurisprudence." 43 To protect its privately-produced public laws, the CAS declared that its arbitral awards are final and binding, subject only to judicial review by the Swiss Federal Court. ${ }^{44}$ Domestic courts lack jurisdiction to challenge CAS awards because the "CAS was intended to usurp the role of domestic courts in the resolution of sport disputes . . ."45

The arbitral awards of the CAS are said to be creating a "lex sportiva, that is, a set of guiding principles and rules in international sports law," which plays a major role in making the CAS more powerful. ${ }^{46}$ The increase in the CAS's power can be attributed to several other factors: it has been designated as the exclusive arbitral body for the World Anti-Doping Agency, the Olympic Games, and for other international sports federations. ${ }^{47}$

\section{ANALYZING THE BENEFITS AND COSTS OF DELEGATING TO THE CAS}

While this paper is a criticism of the CAS's seemingly unfettered power, it must first be acknowledged that though there are costs associated with delegation to the CAS, there are also some benefits to having an independent arbitral body that specializes in dealing with sports-related disputes.

\section{A. Benefits of Delegation}

First, in the absence of an independent sports tribunal, those seeking to resolve disputes would be forced to look to domestic courts, which would either ignore the problems or handle them poorly.48

43. Simon Gardiner ET AL., SPORTs LAW 45 (Routledge 4th ed. 2012) (1998).

44. See General Information, CT. ARB. FOR SPORT, http://www.tas-cas.org/en/generalinformation/frequently-asked-questions.html (last visited Mar. 29, 2015).

45. Marcus F. Mazzucco \& Hilary A. Findlay, Re-Thinking the Legal Regulation of the Olympic Regime: Envisioning a Broader Role for the Court of Arbitration for Sport, 15-16 (Paper presented at the Tenth International Symposium for Olympic Research, Canada, Oct. 29, 2010).

46. Eric T. Gilson, Exploring the Court of Arbitration for Sport, 98 LAW LIBR. J. 503, 504 (2006).

47. See Olympic Charter, INT'L OLYMPIC COMM. (IOC), 105 (Sept. 9, 2013), available at http://www.olympic.org/Documents/olympic_charter_en.pdf; JUA Statutes, INTERNATIONAL JUDO FEDERATION, art. 27 (2003), available at http://www.intjudo.eu/cikk76.

48. See Anthony T. Polvino, Arbitration As Preventative Medicine for Olympic Ailments: The International Olympic Committee's Court of Arbitration for Sport and the 
Moreover, if domestic courts adjudicated sports disputes, athletes and organizations would face conflicting laws across jurisdictions. ${ }^{49}$ There is also the likelihood of "home-field advantage" for athletes litigating in their home countries, and handing these disputes over to the CAS minimizes the potential for bias. ${ }^{50}$

Second, the fiercest proponents of delegation to the CAS believe that delegation legitimizes, not diminishes, state sovereignty. ${ }^{51}$ Several authors point out that the loss of sovereignty is " $[t]$ he most discussed perceived cost of international delegation," but that the fear of the loss of state sovereignty is unwarranted. ${ }^{52}$ Oona Hathaway vehemently disputes what she thinks is a significantly flawed belief, urging us to consider that delegation requires a state actor's consent, and this consent is an exercise of state power. Moreover, she asserts that states are never bound to these acts of delegation because the power to revoke the independent body's decision always remains in the state's hands. She writes,

\begin{abstract}
Even more important than the initial consent to international delegations is the conditional nature of nearly all such delegations. In most international delegations, states retain the power to revoke authority after it has been granted. As a consequence, states remain free from external control in any meaningful sense, for they are controlled by the decisions of the international body only so long as they agree to be. Once their agreement ceases, the control over them ceases as well. ${ }^{53}$
\end{abstract}

Future for the Settlement of International Sporting Disputes, 8 EMORY INT'L L. REV. 347, 358 (1994).

49. See Ian Blackshaw, The Court of Arbitration for Sport: An International Forum for Settling Disputes Effectively 'Within the Family of Sport', 2 ENT. L. 61, 61-62 (2003).

50. An example of this can be seen in cases before the establishment of the CAS, wherein the IOC was the final arbitrator for disputes even when it was itself a party to the dispute. See History of the CAS, COURT OF ARBITRATION FOR SPORT. http://www.tascas.org/en/general-information/history-of-the-cas.html, (last visited Mar. 29, 2015).

51. See Ralf Michaels, The True Lex Mercatoria: Law Beyond the State, 14 IND. J. GLOBAL LEGAL STUD. 447, 447 (2007).

52. Abbas Ravjani, The Court of Arbitration for Sport: A Subtle Form of International Delegation, 2 J. INT'L MEDIA \& ENT. L. 241, 258 (2009).

53. Oona A. Hathaway, International Delegation and State Sovereignty, 71 LAW \& CONTEMP. PROBS. 115, 122 (2008). 
For Hathaway, the act of delegation is "sovereign consent" that demonstrates a state's sovereign ability, instead of undermining it. ${ }^{54}$

Hathaway is not the only proponent of CAS delegation who believes this to be true. Abbas Ravjani agrees that while the loss of state sovereignty is a legitimate concern in some areas, delegation to the CAS is not one of those areas. ${ }^{55}$ Ravjani bolsters her point by arguing that delegation to the CAS is the optimal solution to the international doping problem because the CAS is efficient and effective. ${ }^{56}$ This reasoning is based on the fact that "states have shown a willingness to legitimate the court as is shown by the adoption of the World Anti-Doping Code, which designates the CAS as the final appellate authority for all doping disputes arising from international competition." 57 For Ravjani, the act of delegation alone, by so many nations and federations, legitimizes the CAS as an effective arbitral body. 58

Third, the CAS eliminates the "protracted litigious disputes" that are characteristic of domestic courts. ${ }^{59}$ As Ravjani explains, "states understand that sometimes a specialized body is in a better position to act on a particular international issue and that allowing that body to act on its behalf will produce more efficient outcomes than if they tried to act alone." 60 It is unlikely that domestic courts would be as skilled and efficient as an independent tribunal in resolving sports disputes. Delegation to a specialized body seems like the obvious thing to do since delegation on specific issues provides for efficient outcomes that may not be achievable independently. ${ }^{61}$ Equally important, the CAS has no personal interest in the outcome of disputes, and the absence of personal interest is essential because it gives all parties the benefit of having a neutral arbitrator that will administer fair results.

Finally, proponents of CAS delegation hold that, to be effective, the institution needs to be independent and guarded against judicial

54. Id.

55. Ravjani, supra note 52.

56. Id. at $272-73$.

57. Id.

58. Ravjani, supra note 52, at 258 (referring to Eric Posner and John Yoo who describe few situations in which delegation to tribunals may be effective); see generally Eric A. Posner \& John C. Yoo, Judicial Independence in International Tribunals, 93 CALIF. L. REV. 1 (2005) (exploring the role of international dispute resolution in international politics and explaining how international tribunals gain legitimacy).

59. Darren Kane, Twenty Years on: An Evaluation of the Court of Arbitration for Sport, 4 MELB. J. INT'L L. 611, 612 (2003).

60. Ravjani, supra note 52, at 259 (citing Darren G. Hawkin et. al, Delegation Under Anarchy: States, International Organizations, and Principal-Agent Theory, in DELEGATION AND AGENCY IN INT'L ORGS. 3, 13 (Darren G. Hawkins et al. eds., 2006).

61. See id. 
intervention. ${ }^{62}$ Laurence Helfer and Anne-Marie Slaughter examined the characteristics of an effective international court and have argued that a tribunal's effectiveness is correlated with its independence. ${ }^{63} \mathrm{In}$ other words, the CAS will be effective only if states allow it to act freely and comply with its judgments. ${ }^{64}$ Oona Hathaway agrees with Helfer and Slaughter's view that "effective international tribunals are independent: they are composed of senior, respected jurists with substantial terms; they have an independent fact-finding capacity; their decisions are binding as international law; they make decisions on the basis of 'principle rather than power'; and they engage in high-quality legal reasoning." 65 For the proponents of delegation, the CAS should be hailed as the "world court of sport" because of its specialization and efficiency. ${ }^{66}$

\section{B. Costs of Delegation}

The CAS, as a private transnational lawmaker, receives its power both from international sporting organizations and national governments, but this does not necessarily mean that its rules are legitimate or beyond criticism. While it is important to acknowledge the benefits of delegation to the CAS, it is equally important to point out that it can also impose various costs to states, specifically to the athletes that belong to those states.

To begin, delegating sports disputes to the CAS seems like a good idea at first, but it is only a good idea if the private body a state has authorized to act on a state's behalf is acting fairly. What happens when the actions of the CAS erode core national values? What can states do to spare their athletes from unjustly harsh punishment? Under the CAS's current scheme-nothing. There are 193 governments that have delegated the CAS to adjudicate sports disputes on their behalf, which means that the power of lex sportiva is currently in the hands of 330

62. See generally RichaRd J. BARNET \& John CAVANAGH, Global DREAMS: IMPERIAL CORPORATIONS AND THE NEW WORLD ORDER (1994) (criticizing the power of worldwide conglomerates and arguing that these powers have created a global system that is largely ungoverned and unregulated by nation-states, resulting in negative implications for most of the world's population).

63. See Laurence R. Helfer \& Anne-Marie Slaughter, Toward a Theory of Effective Supranational Adjudication, 107 YALE L.J. 273, 282-87 (1997).

64. See id.

65. Posner \& Yoo, supra note 58, at 5-6 (quoting Helfer \& Slaughter, supra note 63, at 314).

66. Antoine Duval, Lex Sportiva: A Playground for Transnational Law, 19 EUR. L.J. 822,830 (2013). 
individuals. ${ }^{67}$ The interests of tens of thousands of athletes are at stake, yet power is centralized in the hands of the few. When it comes to fairness, there is a great cost to athletes subject to the CAS's jurisdiction because the CAS will inevitably "disagree with, rule against, or render interpretations that run counter to what [national governments] might have wanted, and what the democratic majority might prefer." 68 The CAS has a monopoly over the international sports arena, and it is subject to the minimalist of review standards. ${ }^{69}$ This is made clear in the Federal Code on Private International Law:

1. The award is final from its notification.

2. The award may only be annulled:

a. If a sole arbitrator was designated irregularly or the arbitral tribunal was constituted irregularly;

b. If the arbitral tribunal erroneously held that it had or did not have jurisdiction;

c. If the arbitral tribunal ruled on matters beyond the claims submitted to it or if it failed to rule on one of the claims;

d. If the equality of the parties or their right to be heard in adversarial proceeding was not respected;

e. If the award is incompatible with Swiss public policy. ${ }^{70}$

What happens when the "justice" the CAS administers is unfair? There is no provision in the CAS's Code that provides recourse for a disproportionately harsh award.

Second, some authors have tried to dispel arguments that globalization diminishes state sovereignty and have contended that the CAS functions effectively because it is independent from domestic

67. List of Arbitrators (General List), COURT OF ARBITRATION FOR SPORT, http://www.tas-cas.org/en/arbitration/list-of-arbitrators-general-list.html (last visited Mar. 29, 2015).

68. Karen J. Alter, Delegating to International Courts: Self-Binding vs. Other-Binding Delegation, 71 LAW \& CoNTEMP. PROBS. 37, 39 (2008).

69. Duval, supra note 66, at 833.

70. SwitzerLand's Federal Code ON PRIVATE INTERnational LaW [CPIL] art. 190(2) (Dec. 18, 1987). 
courts. ${ }^{71}$ There are others, however, who have recognized that "[ $\left.t\right]$ he pooling of sovereignty and the delegation of state power to international bodies inevitably have denationalizing effects . . ." 72 Inherent in this framework of independence is the lack of accountability. The CAS is in a league all its own; it self-regulates by its own rules and through its own internal political processes with no external agency to hold it accountable. ${ }^{73}$ The absence of outside pressure invites private bodies like the CAS to abuse their power. ${ }^{74}$ Nations have, in a sense, put their athletes in the hands of a private society that is an isolated legal system functioning under its own principles. ${ }^{75}$ The CAS will become truly legitimate only when its functions and mechanisms can be scrutinized. ${ }^{76}$

Third, while consent to jurisdiction of the CAS is voluntary and states can simply choose not to become a signatory to the World AntiDoping Code (which, as stated above, is a document that makes the CAS the exclusive arbitrator of sports-related disputes arising out of international competitions or involving international athletes), failing to become a signatory means states would be unable to participate in the Olympic Games, host the Olympic Games, or participate in any other international sporting event that requires submission to the Code. ${ }^{77}$ This has led many scholars to question the de facto nature of acceding to jurisdiction. ${ }^{78}$ One author has observed,

The initial idea of the founders that the CAS would not be imposed upon athletes or federations remains in

71. Hathaway, supra note 53, at 122; see also Matthew J. Mitten \& Hayden Opie, "Sports Law": Implications for the Development of International, Comparative, and National Law and Global Dispute Resolution, 85 TUL. L. REv. 269 (2010) (discussing the influence that sports law has had on the development of global dispute resolution and international laws).

72. Alfred C. Aman Jr., Globalization: Legal Aspects 5 (Aug. 28, 2013) (unpublished manuscript) (on file with author).

73. Andreas Fischer-Lescano \& Gunther Teubner, Regime-Collisions: The Vain Search for Legal Unity in the Fragmentation of Global Law, 25 MICH. J. INT'L L. 999, 1010 (Michelle Everson trans., 2004).

74. See generally Alfred C. Aman Jr. \& Peer C. Zumbansen, Transnational Law: Norms, Actors And Processes (unpublished manuscript) (on file with author) (discussing the Foxconn case study and the problems that arise when large corporations engage in private self-regulatory processes without outside accountability).

75. See Duval, supra note 66 , at $827-28$.

76. See id. at 834 .

77. What Happens if a Sports Organization or a Government Does Not Comply With the Code?, WoRlD ANTI DoPING AGENCY (2015), available at https:/www.wada-ama.org/en/ questions-answers/world-anti-doping-code (last visited Apr. 16, 2015).

78. See Stephen A. Kaufman, Note, Issues in International Sports Arbitration, 13 B.U. INT'L L.J. 527, 527-30 (1995) (describing the process of delegation jurisdiction to the CAS in order to compete in a competition). 
principle; however over time, since most international sports competitions have chosen the CAS as its court of choice, the decisions of the Olympics or World Cup trickles down to the [International Federations], [National Olympic Committees], [National Governing Bodies], and ultimately to individual athletes. ${ }^{79}$

There is an obvious imbalance in the distribution of power between the CAS and the countries that submit to its power. Although authors like Oona Hathaway suggest that acceding to CAS jurisdiction is optional and can be revoked at any time, the reality suggests that the opposite is true. Hathaway herself has acknowledged that

[w]hen there are significant asymmetries in power between the parties to an international delegation, the weaker party's consent may reflect the disproportionate influence of the stronger. The most familiar-and extreme-instances of such asymmetric power are found when consent to a delegation is coerced. Less obvious, but more common today, are delegations generated when states with unequal power enter agreements that one or more of them simply cannot afford to refuse. ${ }^{80}$

When access to international sports competitions depends on submitting to the jurisdiction of the CAS, is the decision to become a signatory really a choice? It is almost impossible to remain outside the CAS regime because the benefits forgone by not being subject to its jurisprudence carry heavy consequences. ${ }^{81}$

\section{What Does This Teach Us About Globalization?}

Broadly stated, globalization can be defined as the "process of denationalization of clusters of political, economic, and social activities." 82 The delegation of power to the CAS is a product of this process. Some have argued that " $[t]$ o be sovereign, a state must be independent, which means that the state cannot be put under a duty or obligation by those external to it." 83 While delegation to the CAS

79. Ravjani, supra note 52 , at 250 .

80. Hathaway, supra note 53 , at 137.

81. See id. at 138.

82. Jost Delbrück, Globalization of Law, Politics, and Markets-Implications for Domestic Law-A European Perspective, 1 IND. J. GLOBAL LEGAL STUD. 9, 11 (1993).

83. See Hathaway, supra note 53 , at 121. 
produces quick resolution of doping cases, athletes are forced to live with decisions made by individuals who are not their direct representatives to whom they are not held accountable. ${ }^{84}$ In this way, globalization creates an uneven distribution of power. ${ }^{85}$ As political scientists have observed, there has been a relative fall of state power since the CAS gained popularity. 86

By "relative fall," researchers mean "a partial 'retreat of the state' from a(n) (imagined) position of almightiness in the international and national political scene." 87 The globalization of sports law has all but rendered governments, international bodies, and athletes helpless against the private organization that has begun to take over the transnational legal space.

The relationship between national bodies and the CAS further teaches us that globalization widens the gap between the smaller, less powerful nation-state and the larger transnational institution. In our case, it is not surprising that some athletes feel a growing sense of helplessness as they fight against an external force over which neither they nor their own governments have any control. ${ }^{88}$ For globalization to work, there needs to be a constant flow of communication between the state and the transnational actor.

When all is said and done, the CAS accomplishes what the founders wanted it to achieve: it resolves international sports disputes in a quick and efficient manner, but it also has the potential to greatly undermine the powers of individual states.

84. See U.K. Jha, Democratic Deficits in a Globalizing World: Thy Way Out, 65 INDIAN J. POL. SCI. 531, 531 (2004).

85. See, e.g., Cynthia A. Williams, Corporate Social Responsibility in an Era of Economic Globalization, 35 U.C. DAVIS L. REv. 705, 725 (2002) (stating that Globalization inhibits the ability of nation-states to exercise proactive regulatory power on transnational bodies).

86. Duval, supra note 66 , at 824.

87. Id. (referencing S. GeORge, The Retreat of the STATE: The Diffusion OF POWER IN THE WORLD ECONOMY (1996)).

88. Jeré Longman, Sprinter Leaves Humiliation Behind, N.Y. TrMES (Dec. 19, 2011), available at $\mathrm{http} / / / \mathrm{www}$.nytimes.com/2011/12/20/sports/olympics/sprinter-lashawn-merrittleaves-humiliation-behind.html. 
IV. Proposed Reform: Allowing Reasonable Mistake of Fact as a DEFENSE TO THE STRICT LIABILITY SCHEME

\section{A. Allowing Reasonable Mistake of Fact as a Defense to the Strict Liability Scheme}

While the use of strict liability seems to be an easy and cost-effective way of handing out sanctions, this scheme fails to address the inherent unfairness endured by athletes who inadvertently ingest banned substances. We have seen the harshest drawback of this scheme: that it punishes innocent athletes like Andreea Răducan and Jessica Hardy. The Code drafters themselves have previously admitted that a strict liability test is likely to be unfair for some athletes. ${ }^{89}$ Despite this realization, they have failed to mitigate the effects of this unfairness, suggesting that an unfair application of the rules is the lesser of two evils. ${ }^{90}$ Since it may be impossible to completely eliminate unfairness with a strict liability model, allowing athletes to call upon a reasonable "mistake of fact" defense would make for a more equitable judicial process.

The "mistake of fact" or "ignorance of fact" doctrine is largely built upon Levett's Case, a criminal case decided in $1638 .{ }^{91}$ In this case, the defendant, under the mistaken belief that there was a burglar in his home, killed Frances, who was the friend of his servant.92 The court held that this act was not manslaughter because the defendant committed the act "ignorantly, without intention of hurt to the said Frances." 93 After this decision, courts began to adopt the doctrine that a "factual mistake is a reasonable one that negates the culpable mental state required for the commission of the offense."94

For inadvertent doping cases, the "mistake of fact" defense should be allowed if an athlete believed in good faith that the substance they were ingesting was not on the banned-substance list. This defense should include a mistake of fact caused by reasonable reliance on information provided by another person; a mistake of fact caused by the act or default of another person; or a mistake of fact caused by an accident or some other circumstance beyond the athlete's control, and

89. WADA Code 2003, supra note 19, at art. 2.1.

90. See id. at art. 10.5.

91. Edwin R. Keedy, Ignorance and Mistake in the Criminal Law, 22 HARV. L. REV. 75, $79-80$ (1908).

92. $I d$.

93. Rex v. Levett, (1638) 79 Eng. Rep. 1064 (K.B.).

94. Henderson v. State, No. A-3929, 1992 WL 12153172, at *1 (Alaska Ct. App. May 6, 1992). 
the athlete took reasonable precautions and exercised due diligence to avoid ingesting a banned substance. If, like Hardy, an athlete took precautionary measures and did not know, and had no reason to suspect that they were ingesting a banned substance, then they should not be held liable.

Like any model, the one proposed has its limitations. Supporters of the strict liability doctrine point to the difficulty of proving mens rea as the explanation for the emergence of strict liability. With the proposed model, the CAS would have to prove that the athlete ingested a banned substance with the requisite culpable mental state. Subjective mental states are often difficult to prove, and the CAS would have to rely on circumstantial evidence. Strict liability supporters often cite increased administrative costs associated with verifying a defendant's thoughts as a reason to abandon the mens rea requirement. ${ }^{95}$

However, this is only true when we expect an exceptionally large number of cases to reach the court. ${ }^{96}$ Because this is not the case, and there are not an exceptionally large number of cases before the CAS, the court can afford to employ a mens rea requirement. To date, the CAS has published a total of 439 non-confidential cases since its first arbitration procedure in $1986 .{ }^{97}$ There is no indication of the number of confidential cases, but surely this is not an exceptionally large number for a twenty-eight year time period. Whatever the case may be, accidentally ingesting a banned substance would eliminate mens rea, which exists to prevent disproportional punishment as well as punishment of blameless conduct.

Allowing the reasonable mistake of fact defense would provide greater fairness to athletes who unintentionally ingest banned substances, while still adequately punishing those who had the culpable mental state required for the commission of the offense. Besides being stripped of their medals and being unable to compete, athletes face the inevitable result of being labeled a cheater. As long as the WADA continues to operate under a strict liability framework, athletes like Răducan and Hardy will continue to endure disproportionately harsh sanctions.

95. See Assaf Hamdani, Mens Rea and the Cost of Ignorance, 93 VA. L. REV. 415, 418 (2007).

96. See generally Francis Bowes Sayre, Public Welfare Offenses, 33 CoLUM. L. REV. 55, 69 (1933) (explaining that criminalizing petty regulations places strain on the criminal system).

97. Case Law Documents, CT. ARB. FOR SPORT, http://jurisprudence.tas-cas.org/sites/ CaseLaw/Shared\%20Documents/Forms/All\%20Decisions.aspx (last visited Mar. 29, 2015). 


\section{CONCLUSION}

It cannot be disputed that athletes need to play by a certain set of rules; this is the nature of international competition. That the CAS is carrying out an essential function cannot be questioned, but for some athletes, the advent of the CAS's strict liability scheme has been unpleasant. The simple fact is that the CAS's private lawmaking takes away a state's power to exercise authority over its own athletes. The institution has unbridled autonomous rulemaking powers, it lacks accountability, and provides hardly any recourse for athletes for whom "justice" is unfair. The CAS owes its validity to the fact that it is recognized and enabled by the state, ${ }^{98}$ but in delegating its powers, the state must remember that it has a duty to protect the interests of its citizens. ${ }^{99}$

98. See generally Ralf Michaels \& Nils Jansen, Private Law Beyond the State? Europeanization, Globalization, Privatization, 54 AM. J. CoMP. L. 843, 860 (2006) (explaining that private law is part of a coherent legal system owing its validity and legitimacy to the fact that it is conceived as a coherent whole and enacted or enabled by the state).

99. See Andrew Linklater, The Evolving Spheres of International Justice, 75 INT'L AFF. 473,478 (1999). 